\title{
Background ionizing radiation and semen parameters of men with reproductive problems
}

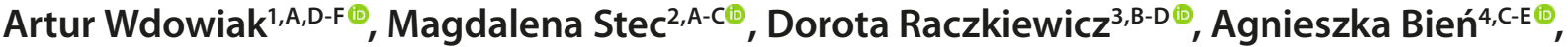 \\ Grażyna Iwanowicz-Palus ${ }^{4, C-D \oplus}$, Lech Panasiuk ${ }^{5, E-F} \oplus$ \\ ${ }^{1}$ Diagnostic Techniques Unit, Faculty of Health Sciences, Medical University, Lublin, Poland \\ 2 Professor W. Orlowski Memorial Hospital, The Centre of Postgraduate Medical Education, Warsaw, Poland \\ ${ }^{3}$ Institute of Statistics and Demography, Collegium of Economic Analysis, SGH School of Economics, Warsaw, Poland \\ ${ }^{4}$ Chair and Department of Development in Midwifery, Faculty of Health Sciences, Medical University, Lublin, Poland \\ ${ }^{5}$ Institute of Rural Health, Lublin, Poland
}

A - Research concept and design, B - Collection and/or assembly of data, C - Data analysis and interpretation,

$D$ - Writing the article, $E$ - Critical revision of the article, $F$ - Final approval of article

Wdowiak A, Stec M, Raczkiewicz D, Bień A, Iwanowicz-Palus G, Panasiuk L. Background ionizing radiation and semen parameters of men with reproductive problems. Ann Agric Environ Med. 2020; 27(1): 43-48. DOI: 10.26444/aaem/118155

\section{Abstract}

Introduction and objective. The male reproductive system constitutes a set of tissues which are particularly sensitive to external factors. The aim of the study was to analyze the relationship between background radioactivity and the quality of the semen of the men who have reported to the infertility treatment facility in 2000-2016 in the Lublin region of eastern Poland.

Materials and method. The radioactivity of the ground-level air layer obtained from the Institute of Meteorology and Water Management in Włodawa in the Lublin region was analysed. 4,250 spermiograms of patients who reported to the treatment facility for the first time due to infertility were analysed and correlated to background radioactivity in the Lublin region in 2000-2016.

Results. A long-term decrease in the percentage of morphologically normal spermatozoa of the patients was observed $(r=-0.970 ; p<0.001$ in 2000-2009 and $r=-0.925 ; p=0.003$ in 2010-2016). Men's age correlated negatively with sperm motility $(r=-0.164 ; p=0.009)$ and morphology $(r=-0.186 ; p=0.009)$. The percentage of spermatozoa with normal morphology was lowered by beta-isotopes of artificial origin in the air in $2000-2009(r=-0.655 ; p=0.040)$ and by the exposure to gamma radiation of the ground-level atmosphere in 2010-2016 ( $r=-0.676 ; p=0.048)$. The percentage of sperm vitality was lowered by gamma radiation in the atmosphere $(r=-0.636 ; p=0.006)$, but improved by beta isotopes in precipitation $(r=0.686 ; p=0.002)$ in the whole of the analyzed period.

Conclusions. The percentage of morphologically normal spermatozoa in patients who reported to the infertility treatment depends not only on the age of patient, but also on beta-isotopes of artificial origin and gamma radiation in the atmosphere. Beta isotopes in precipitation affect the improvement of sperm vitality.

Key words

ionizing radiation, men, semen analysis, sperm quality, reproduction, male infertility

\section{INTRODUCTION}

Radioactivity is an inseparable element of our lives and the environment. In the environment we deal with radioactive isotopes of both natural and artificial origin caused by human activities. Natural radioactivity originates from radioactive isotopes triggered by the actions of cosmic rays directed on the nuclei of nitrogen, oxygen and argon atoms present in the atmosphere. Natural radioisotopes are also to be found in the soil and the earth's crust [1].

The intensity of the radioactive radiation on earth has been changing over thousands of years. The level of radioactivity also varies depending on the geographical location. Changes in the intensity of the radioactive radiation in the past have influenced the physiology, mutation and selection of organisms that live on earth $[1,2]$. These processes are in still progress, and the available literature confirms the impact of background radioactivity on human health $[3,4]$.

Address for correspondence: Agnieszka Bień, Chair and Department of Development in Midwifery, Faculty of Health Sciences, Medical University, Lublin, Poland E-mail: agnesmbien@gmail.com

Received: 14.01.2020; accepted: 11.02.2020; first published: 02.03.2020
The effects exerted by the ionizing radiation on living organisms directly depend both on the size of the dose and the kind of radiation. The biological consequences derive from the radiation conditions, such as the strength of the dose, way of fractioning, mass and type of tissues exposed to radiation, as well as their oxygenation. The effects of the exposure to radioactivity depends also on the individual biological characteristics of a body [5-8].

According to one theory, even small doses of radioactive radiation can have a beneficial effect on the functioning of living organisms. This phenomenon has been described as the hormetic effect [7,9-11]. Undoubtedly, large doses of radiation have a negative impact on the physiology of the body. The basic pathomechanism of cell damage caused by the influence of ionizing radiation is the formation of free radicals. Oxidative stress is the cause of the damage to the DNA and other macromolecules [12, 13].

The male reproductive system constitutes a set of tissues which are particularly sensitive to external factors. A mature sperm practically does not have any self-repair mechanisms of its own DNA [14]. It can therefore be expected that even small doses of background radioactivity may affect the male reproductive functions. 


\section{OBJECTIVE}

The aim of the study was to analyze the relationship between the background activity and the quality of semen of men treated for infertility for the first time in 2000-2016 in the Lublin region of eastern Poland.

\section{MATERIALS AND METHOD}

Radiation. The radioactivity of the ground-level air layer obtained from the Institute of Meteorology and Water Management in Włodawa in the Lublin region was analysed. The data on radioactivity were carried out using the FHT59Si device in $\mathrm{Bq} / \mathrm{m}^{2}$ units at the Early Radiation Detection Network Station. The analyzed data on radioactivity were as follows:

- radioactive concentration of alpha isotopes of artificial origin in the air;

- radioactive concentration of beta isotopes of artificial origin in the air;

- radioactive concentration of alpha isotopes of natural origin in the air;

- radioactive concentration of beta isotopes in the total monthly drop;

- value of the exposure dose of gamma radiation.

Study group. Data on semen parameters were analyzed in patients treated for infertility. The patients presented themselves the first time to Independent Public Clinical Hospital No. 1, NZOZ Ovum (Non-Public Health Care Facility) and the Luxmed Medical Centre in the Lublin region in years 2000-2016. The spermiograms of the couples with WHO infertility diagnosis were analyzed, and the men were sex and alcohol abstinent for 3-5 day preceding the ejaculation. The exclusion criteria from the study group were: absence of semen in the ejaculate or the number of spermatozoa insufficient to conduct a reliable semen analysis. In total, data on the semen parameters of 4,250 men was obtained, 250 men in each of the 17 analyzed years. The study was approved by the Bioethics Committee of the Medical University in Lublin (Approval No. KE-0254/306/2016).

Semen evaluation. The semen samples from 2000 - 2009 were evaluated according to the WHO 1999 standards, and from 2010 - 2016 according to the WHO 2010 standards. According to WHO 2010 standards concerning sperm motility, only the progressive motility was evaluated. In the WHO 1999 standards, the progressive motility was divided into fast and slow. In order for the study to comply with the WHO 2010 standards, both the fast and slow progressive motility were then summed-up. Due to the modifications related to the WHO 2010 sperm morphology, morphologically normal spermatozoa were analysed separately in two sub-periods - 2000-2009 (according to WHO 1999) and 2010-2016 (according to WHO 2010) [15-17].

Statistical methods. Statistical analysis of the collected data was performed in statistical computer package STATISTICA (StatSoft, Poland). Arithmetic means (M) and standard deviations (SD) were estimated for continuous variables. Time series of radioactivity of the ground-level atmospheric layer, age and male semen parameters were analysed using
Person's correlation coefficients between the levels of studied phenomena and years. In the case of the presence of linear trends, their parameters were estimated using regression models of the studied phenomena, with t explanatory variable representing the number of time series, with estimation of coefficient of determination. Pearson's correlation coefficient was also used to analyse correlation between age and semen parameters, and between radioactivity and mean semen parameters in 2000-2016. The regression models of semen parameters versus radioactivity of the groundlevel atmosphere layer were also estimated. The selection of explanatory variables for the regression models was performed by backward step regression. The significance level of 0.05 was considered to be statistically significant.

\section{RESULTS}

Changes in radioactivity of ground-level atmosphere. The concentration of radioactive beta isotopes of artificial origin in the air in $20002-2016$ fluctuated from $0.001-0.312 \mathrm{~Bq} / \mathrm{m}^{3}$, and the alpha isotopes from $0.003-0.077 \mathrm{~Bq} / \mathrm{m}^{3}$ (Fig. 1). The concentration of the radioactive beta isotopes of artificial origin in the air was generally higher than that of alpha isotopes (except for 2013 and 2014). There were no significant long-term increasing nor decreasing trend in the concentrations of the beta isotopes $(\mathrm{r}=0.307 ; \mathrm{p}=0.231)$ and the alpha isotopes $(\mathrm{r}=0.173 ; \mathrm{p}=0.507)$.

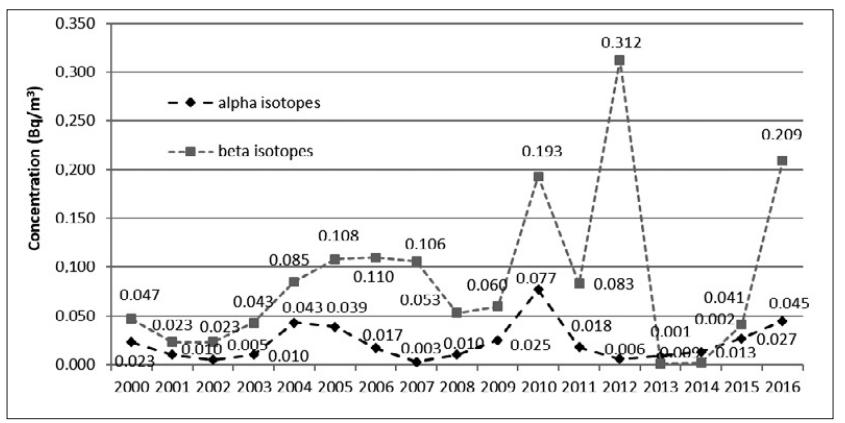

Figure 1. Radioactive concentration of alpha and beta isotopes of artificial origin in the air of the Lublin region (2000-2016)

In the studied years, the concentration of radioactive alpha isotopes of natural origin in the air fluctuated from 3.54 - $10 \mathrm{~Bq} / \mathrm{m}^{3}$, without significant increasing nor decreasing trend $(\mathrm{r}=-0.027 ; \mathrm{p}=0.920)$. However, the concentration of radioactive beta isotopes in the total monthly fall in the Lublin region had an increasing trend in 2000-2016 ( $\mathrm{r}=0.602$; $\mathrm{p}=0.011)$. In the first half of the studied period it fluctuated around $6 \mathrm{~Bq} / \mathrm{m}^{2}$, while in the second half - around $8 \mathrm{~Bq} / \mathrm{m}^{2}$ (Fig. 2).

The strength of the exposure dose of gamma radiation in the Lublin region in 2000-2006 oscillated around $82 \mathrm{nGy} / \mathrm{h}$. In the following years, it gradually decreased to $61.5 \mathrm{nGy} / \mathrm{h}$ in 2012, and then increased again to about $80 \mathrm{nGy} / \mathrm{h}$ in 2014 , and remained at this level until 2016 (Fig. 3).

Changes in age and semen parameters. In 2000-2016, the average age of the men who presented themselves for infertility treatment increased systematically from 30.9 years in 2000 to 33.5 years in 2016, by 0.14 year, on average, from year to year $\left(\mathrm{y}_{\mathrm{t}}=0.14 \mathrm{t}+30.75, \mathrm{r}^{2}=0.83, \mathrm{r}=0.913\right.$; $\left.\mathrm{p}<0.001\right)$. 


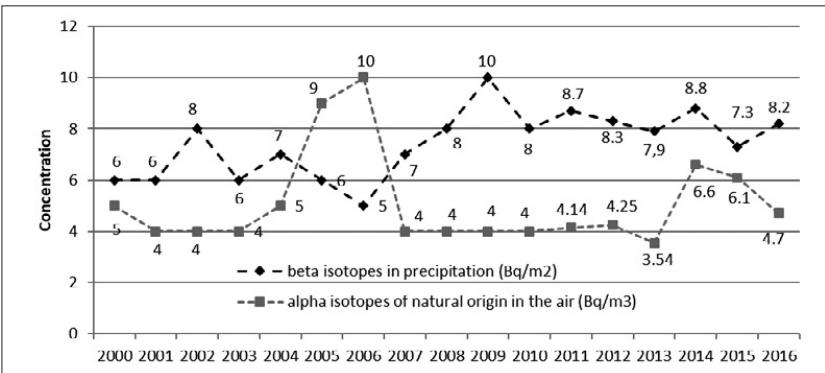

Figure 2. Radioactive concentration of alpha isotopes of natural origin in the air and beta isotopes in the total monthly precipitation in the Lublin region (2000-2016)

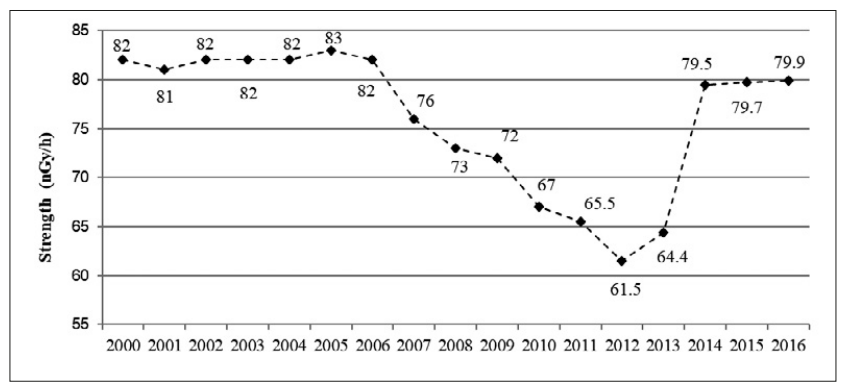

Figure 3. Value of the strength the exposure dose of gamma radiation in the Lublin region (2000-2016)

During the study period, the average volume of ejaculate increased from $3.4 \mathrm{~mL}$ in 2000 to $4.0 \mathrm{~mL}$ in 2016, while the total sperm count in ejaculate and the density of ejaculate almost doubled (total sperm count in the ejaculate from 81.9 million in 2000 to 155.8 million in 2016, and the density of ejaculate from $23.9 \mathrm{million} / \mathrm{mL}$ in 2000 to $40.9 \mathrm{million} / \mathrm{mL}$ in 2016).

The average percentage of sperm in progressive motility in the examined patients oscillated around $40 \%$, except for 2011 and 2012, when they oscillated around 18\%.

The average percentage of morphologically normal spermatozoa in the examined men showed decreasing trends in 2000-2009 $\left(\mathrm{y}_{\mathrm{t}}=56.99-3.32 \mathrm{t}, \mathrm{r}^{2}=0.94, \mathrm{r}=-0.970\right.$; $\mathrm{p}<0.001)$ and in 2010-2016 $\left(\mathrm{y}_{\mathrm{t}}=22.74-3.19 \mathrm{t}, \mathrm{r}^{2}=0.86, \mathrm{r}=-0.925\right.$; $\mathrm{p}=0.003)$. In 2000, the average percentage of morphologically normal spermatozoa was $54.9 \%$ and in the subsequent years it decreased by 3.32 percentage points, on average, in each of the following years, until it eventually reached to $25.5 \%$ in 2009. In 2010, the average percentage of morphologically normal spermatozoa was $24.4 \%$ and in subsequent years it decreased by an average of 3.19 percentage points in each of the following years, until $2.9 \%$ in 2016 .

The average percentage of viable spermatozoa had a increasing trend $\left(\mathrm{y}_{\mathrm{t}}=32.14-4.11 \mathrm{t}, \mathrm{r}^{2}=0.87, \mathrm{r}=0.932 ; \mathrm{p}<0.001\right)$ and increased by 4.1 percentage points, on average, from year to year between $2000-2016$. In 2000, the average percentage of viable sperm was $45.2 \%$, while in 2016 it was much higher and equal to $73.6 \%$ (Tab. 1).

Correlations between radioactivity of ground-level atmosphere and age, and semen parameters. A significant negative correlation between the age of the studied men and the percentage of sperm in the progressive motility $(\mathrm{r}=-0.164$; $\mathrm{p}=0.009)$ and the percentage of morphologically normal spermatozoa $(r=-0.186 ; p=0.009)$ were found. However, there was no correlation between the age of the studied men and other analyzed parameters of their semen, such as: ejaculate volume $(\mathrm{r}=0.005 ; \mathrm{p}=0.936)$, ejaculate density $(\mathrm{r}=-0.059$; $\mathrm{p}=0.355)$, total sperm count in ejaculate $(\mathrm{r}=-0.078 ; \mathrm{p}=0.217)$ and the percentage of viable spermatozoa $(r=-0.073 ; p=0.253)$.

There were no significant correlations between the concentrations of the five considered radioactive isotopes and mean values of the four parameters of the semen: volume of ejaculate, number of spermatozoa in ejaculate, density of ejaculate and percentage of sperm in progressive motility ( $p>0.05$, Tab. 2$)$. The average percentage of viable sperm correlated positively with the concentration of beta radioactive isotopes in the precipitation $(r=0.686 ; p=0.002)$, but negatively with the value of the strength of the exposure of the gamma radiation $(r=-0.636 ; p=0.006)$. Additionally, the

Table 1. Semen parameters in studied males $(M \pm S D)$

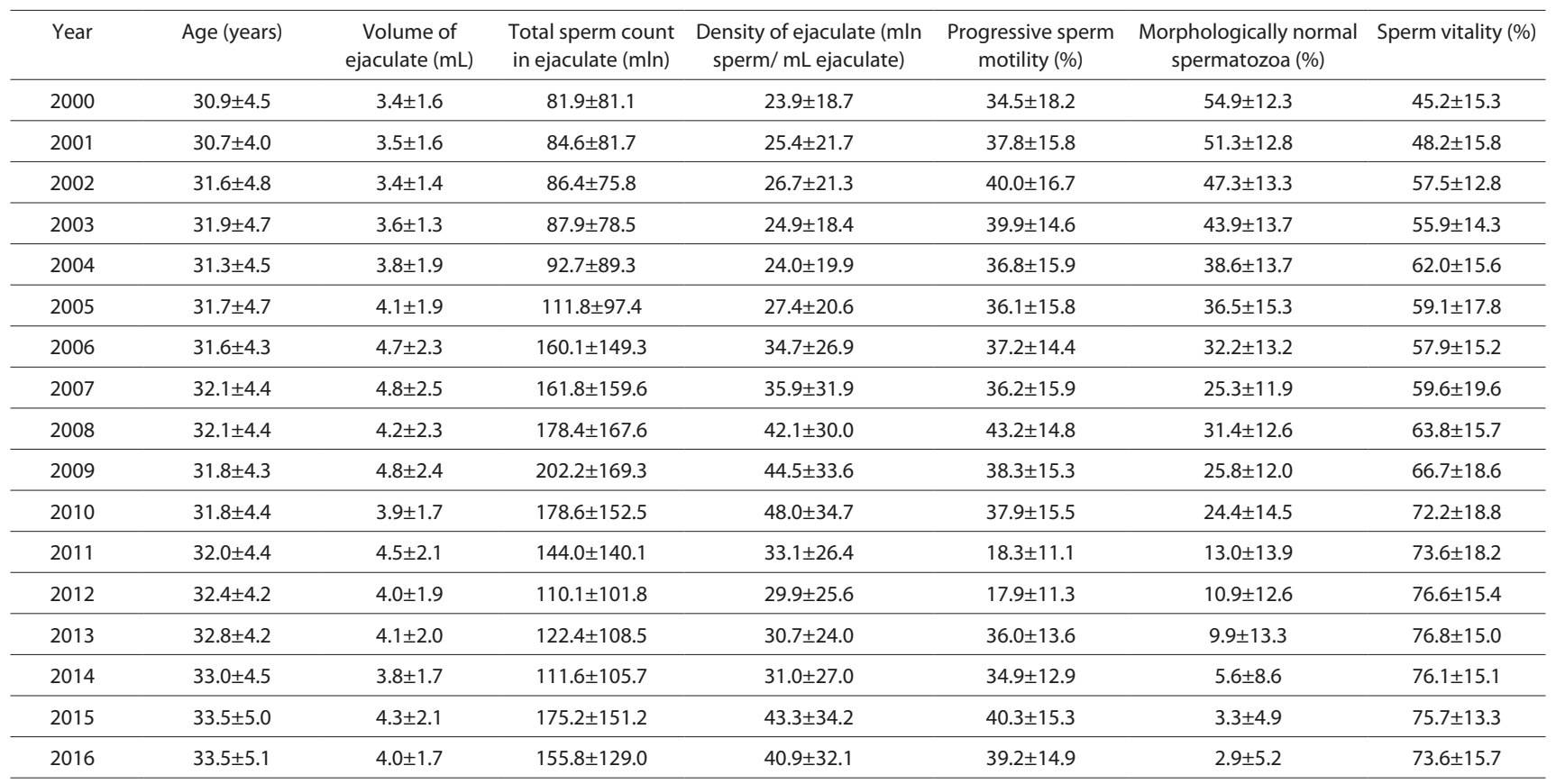


Table 2. Correlations between semen parameters in the studied males and radioactivity of the ground-level atmosphere in the Lublin region (2000-2016)

\begin{tabular}{|c|c|c|c|c|c|c|c|c|c|c|c|c|c|c|c|}
\hline \multirow[t]{2}{*}{ Radiation } & & \multicolumn{2}{|c|}{$\begin{array}{c}\text { Volume of } \\
\text { ejaculate }(\mathrm{mL})\end{array}$} & \multicolumn{2}{|c|}{$\begin{array}{c}\text { Total sperm } \\
\text { count in } \\
\text { ejaculate }(\mathrm{mln})\end{array}$} & \multicolumn{2}{|c|}{$\begin{array}{l}\text { Density of } \\
\text { ejaculate } \\
(\mathrm{mln} / \mathrm{mL})\end{array}$} & \multicolumn{2}{|c|}{$\begin{array}{c}\text { Progressive } \\
\text { sperm motility }\end{array}$} & \multicolumn{2}{|c|}{ Sperm vitality } & \multicolumn{2}{|c|}{$\begin{array}{c}\text { Morphologically } \\
\text { normal } \\
\text { spermatozoa } \\
\text { WHO } 1999\end{array}$} & \multicolumn{2}{|c|}{$\begin{array}{c}\text { Morphologically } \\
\text { normal } \\
\text { spermatozoa } \\
\text { WHO } 2010\end{array}$} \\
\hline & & $r$ & $p$ & $r$ & $p$ & $r$ & $p$ & $r$ & $p$ & $r$ & $p$ & $r$ & $p$ & $r$ & $p$ \\
\hline \multirow{3}{*}{$\begin{array}{l}\text { Radioactive } \\
\text { concen- } \\
\text { tration }\end{array}$} & $\begin{array}{l}\text { Alpha isotopes of artificial } \\
\text { origin in the air }\left(\mathrm{Bq} / \mathrm{m}^{3}\right)\end{array}$ & -0.072 & 0.784 & 0.289 & 0.261 & 0.417 & 0.096 & 0.172 & 0.510 & 0.187 & 0.472 & -0.037 & 0.919 & 0.538 & 0,213 \\
\hline & $\begin{array}{l}\text { Beta isotopes in } \\
\text { precipitation }\left(\mathrm{Bq} / \mathrm{m}^{2}\right)\end{array}$ & 0.220 & 0.395 & 0.425 & 0.089 & 0.489 & 0.056 & -0.236 & 0.362 & 0.686 & 0.002 & -0.415 & 0.233 & 0.094 & 0,841 \\
\hline & $\begin{array}{l}\text { Alpha isotopes of natural } \\
\text { origin in the air }\left(\mathrm{Bq} / \mathrm{m}^{3}\right)\end{array}$ & 0.212 & 0.415 & 0.027 & 0.919 & -0.085 & 0.746 & 0.080 & 0.761 & -0.112 & 0.667 & -0.161 & 0.656 & -0.583 & 0,170 \\
\hline \multicolumn{2}{|c|}{$\begin{array}{l}\text { Value of exposure dose to gamma } \\
\text { radiation }(n G y / h)\end{array}$} & $-0,330$ & 0.196 & -0.353 & 0.165 & -0.368 & 0.146 & 0.398 & 0.101 & -0.636 & 0.006 & 0.370 & 0.098 & -0.676 & 0.048 \\
\hline
\end{tabular}

average percentage of morphologically normal spermatozoa correlated negatively with beta radioactive isotopes in the air of the region in 2000-2009 ( $\mathrm{r}=-0655 ; \mathrm{p}=0.040)$ and the strength of the dose of gamma radiation in this region in $2010-2016(\mathrm{r}=-0.676 ; \mathrm{p}=0.048)$.

Regression models of semen parameters versus radioactivity of ground-level atmosphere. In the regression model of the average percentage of viable spermatozoa (Fig. $4, y=24.94+5.36 x$ ), the average percentage of the viable sperm were higher, on average, by 5.36 percentage points, with an increase in beta radioactive isotopes in the precipitation by $1 \mathrm{~Bq} / \mathrm{m}^{2}$. In this regression model, the effect of gamma radiation on the average percentage of the viable spermatozoa was not significant because of significant correlation between the strength of the gamma dose exposure and the beta radioactive isotope concentration $(\mathrm{r}=-0.86 ; \mathrm{p}=0.013)$.

In the regression model of average percentage of morphologically normal spermatozoa in 2000-2009 (Fig. 5, $y=51.83-199.27 x$ ), the average percentages of morphologically normal spermatozoa, on average, was lower by 2.4 percentage points, with a simultaneous increase in the radioactive beta isotopes of artificial origin in the air by $100 \mathrm{~Bq} / \mathrm{m}^{3}$.

In the regression model of the average percentage of morphologically normal spermatozoa in the 2010-2016 (Fig.

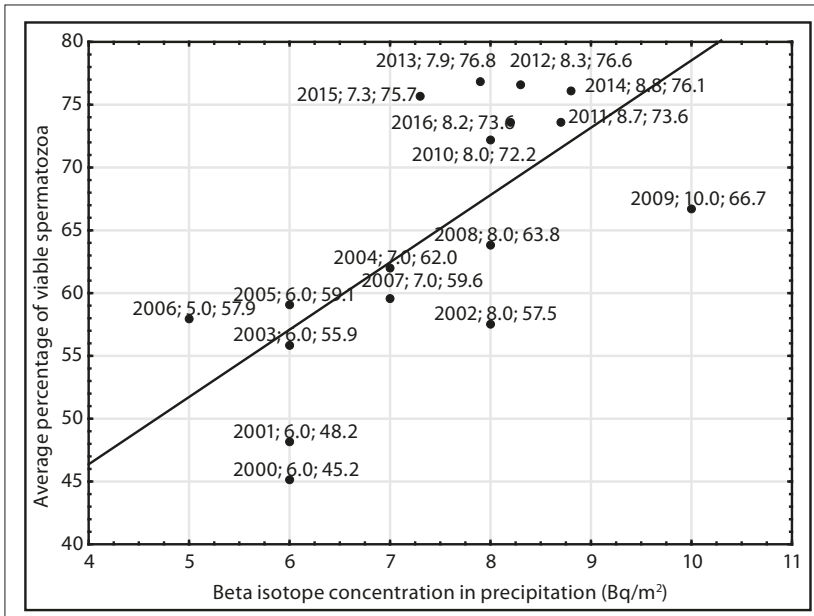

labels: year; isotope concentration; percentage of viable spermatozoa

Figure 4. Average percentage of viable spermatozoa in the studied males versus beta isotope concentrations in precipitation in the Lublin region (2000-2016)

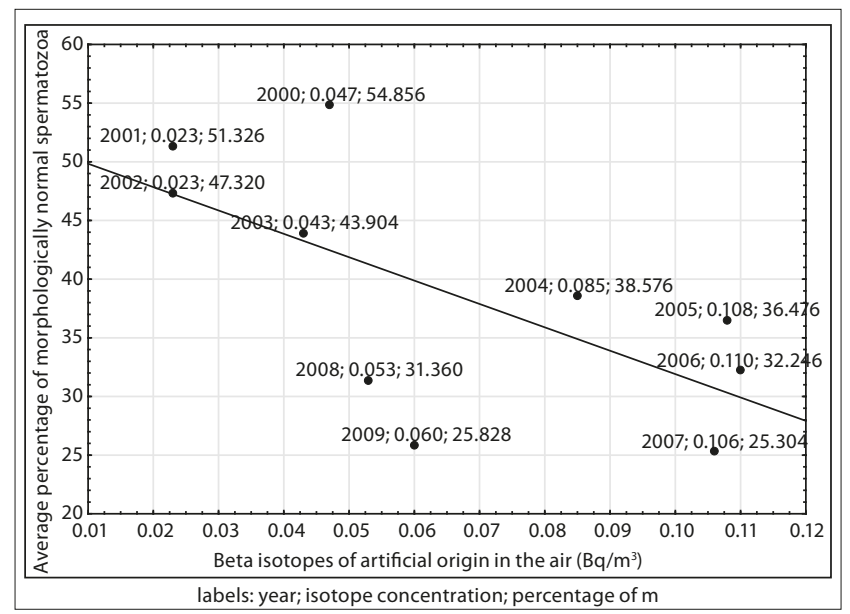

Figure 5. Average percentage of morphologically normal spermatozoa in the studied males versus the concentrations of beta isotopes of artificial origin in the air of the Lublin region (2000-2009)

$6, y=52.11-0.59)$, the average percentage of morphologically normal spermatozoa was lower, on average, by 0.59 percentage points, with a simultaneous increase in the strength value of the gamma radiation exposure dose by $1 \mathrm{~Gy} / \mathrm{h}$ in those years.

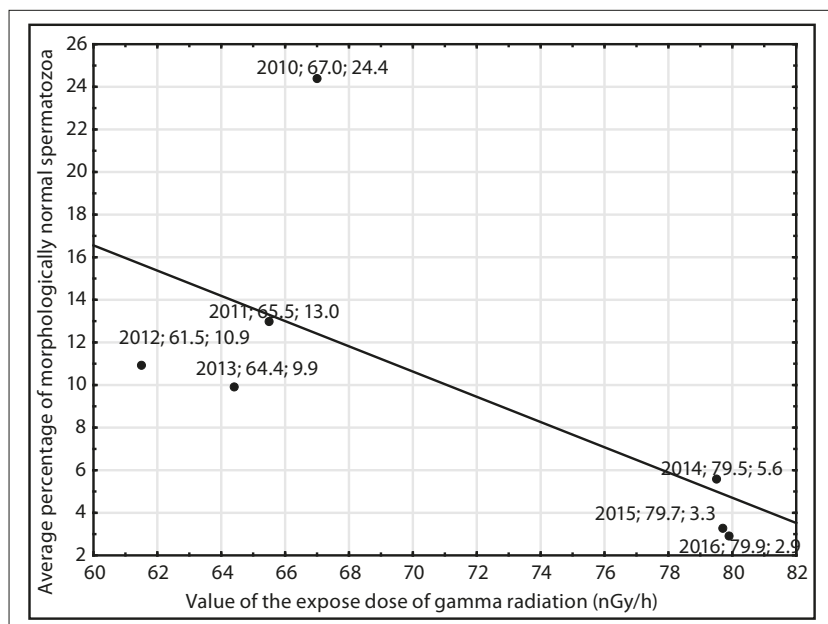

labels: year; isotope concentration; percentage of morphologically normal spermatozoa

Figure 6. Average percentage of morphologically normal spermatozoa in the studied males versus the value of the exposure dose of gamma radiation in the Lublin region (2010-2016) 


\section{DISCUSSION}

The conducted study indicated that background radiation has a negative influence on the sperm morphology and viability. Until now, studies focusing on the effects of natural background radiation (NBR) on male seed have been published by Premi S. et al, which focused on the genetic material of the sperm. Research by Premi S. et al. analyzed the AZFc region using the DNA from blood and semen of 100 males living near the coastal peninsula in Kerala (India), exposed to NBR, along with 50 other normal fertile males. This study proved the presence of the impact of natural background radiation on the human Y chromosome owing to its haploid status and clonal inheritance [18]. Moreover, further research by Permi S. et al. indicated the presence of tandem duplication and copy number polymorphism of the SRY gene in patients with sex chromosome anomalies, and males exposed to natural background radiation [19]. Both Permi S. et al. and Pathak D. also confirmed the mutagenic effect of NBR on the sperm Y chromosome [20,21].

Other scientific reports discussing the influence of radiation on the quality of semen address the radioactivity related to the work environment. The study by Kumar et al. among volunteers from various hospital-exposed diagnostic or therapeutic radiation $(X / \beta / \gamma$ rays) facilities, demonstrated an adverse effect of the radioactivity on motility characteristics, viability, and morphological abnormalities of the semen, which is in line with the results of the presented research. This study also demonstrated that the workers exposed to radioactive factors presented both a higher level of sperm DNA fragmentation and a significant number of hypermethylated spermatozoa, in comparison to the nonexposed group [22]. Research by Kumar et al., indicted that exposure to radioactivity caused by the work environment leads to disorders in the oxidase-reduction system of the semen, which may explain the pathomechanisms of sperm dysfunction found in our studies [12]. A similar observation concerning the erythrocytes of subjects professionally exposed to radiation have been presented by Kłuciński et al [23].

In the current study, the most adverse implications on semen morphology were related to gamma radiation. The harmful effects of this radiation on male sperm were also confirmed by the results of a study by Alvarez R. et al. who indicated that this kind of radiation has effects on the occurrence of sperm DNA damage [24]. Such a negative effect of gamma radiation has likewise been described in an animal model by Saiyad Musthafa M. et al. After irradiation, they observed disorders in the endocrine function of male gonads in fish [25]. Verçosa P et al. also used an animal model to observe a decrease in the fertility in Panstrongylus megistus insects after exposure to gamma radioactivity [26].

The negative influence was found of radioactivity on some semen parameters related to the isotopes present in the air. A negative correlation between isotopes in the precipitation and semen parameters was also observed. This phenomenon could be explained by the fact that precipitation eliminates radioactive isotopes from the air, and in general has a cleansing effect on pollutants present in the air.

Scientific reports concerning the relationship between semen quality and men's age remain ambiguous. Nevertheless, the conducted study indicated correlation between the men's age and a decrease of both sperm motility and percentage of morphologically normal spermatozoa. Thus, these observations are in line with the meta-analysis conducted by Johnson et al. on 93,839 cases and published in 90 researches [27]. These authors proved that the volume of semen, the count of morphologically normal spermatozoa and sperm in the progressive motility, all decrease with age, while the semen density remains unchanged. Johnson et al., however, noticed a progressive decrease in sperm density in the studied years. This phenomenon has been described in numerous reports concerning Western Europe, the USA and Australia [27].

The research results of the current study suggest that the radioactivity of the ground-level atmosphere can have an adverse effect on the male semen parameters. However, making such far-fetched conclusions seems to be too abrupt at the moment. As indicated by the obtained results and the results obtained by other researchers, the semen parameters depend both on various criterion linked with such determinants as: the environment, health and lifestyle, and epigenetics of past generations. The observed dependencies may, however, provide the foundation for to further future population studies concerning the effects of background radiation on male fertility.

\section{CONCLUSIONS}

In 2000-2016, a long-term increase in the age and a decrease in the average percentages of morphologically normal spermatozoa was observed among men presenting to medical facilities due to their infertility. The men's age proved to have an adverse effect on sperm motility and morphology. The percentage of sperm with normal morphology was lowered by beta-isotopes of artificial origin present in the air in 2000-2009, as well as by exposure to gamma radiation of the ground-level atmosphere in 2010-2016. During the whole researched period, the increase of beta isotopes in the precipitation associated with the improvement in sperm viability.

\section{REFERENCES}

1. Møller AP, Mousseau TA. The effects of natural variation in background radioactivity on humans, animals and other organisms. Biol Rev Camb Philos Soc. 2013; 88(1): 226-54. https://doi.org/10.1111/j.1469185X.2012.00249.x

2. Geras'kin SA. Ecological effects of exposure to enhanced levels of ionizing radiation. J Environ Radioact. 2016; 162-163: 347-357. https:// doi.org/10.1016/j.jenvrad.2016.06.012

3. Hladik D, Tapio S. Effects of ionizing radiation on the mammalian brain. Mutat Res. 2016; 770(Pt B): 219-230. https://doi.org/10.1016/j. mrrev.2016.08.003

4. Koturbash I, Jadavji NM, Kutanzi K, Rodriguez-Juarez R, Kogosov D, Metz GAS, et al. Fractionated low-dose exposure to ionizing radiation leads to DNA damage, epigenetic dysregulation, and behavioral impairment. Environ. Epigenet. 2017; 31; 2(4): dvw025. https://doi. org/10.1093/eep/dvw025

5. Gaut B, Yang L, Takuno S, Eguiarte LE. The patterns and causes of variation in plant nucleotide substitution rates. Annu Rev Ecol Evol Syst. 2011; 42: 245-266. https://doi.org/10.1146/annurevecolsys-102710-145119

6. Gryz K, Karpowicz J, Leszko W, Zradziński P. Evaluation of exposure to electromagnetic radiofrequency radiation in the indoor workplace accessible to the public by the use of frequency-selective exposimeters. Int J Occup Med Environ Health. 2014; 27(6): 1043-54. https://doi. org/10.2478/s13382-014-0334-0. 
7. Burgio E, Piscitelli P, Migliore L. Ionizing radiation and human health: reviewing models of exposure and mechanisms of cellular damage. An epigenetic perspective. Int J Environ Res Public Health. 2018; 15(9): pii: E1971. https://doi.org/10.3390/ijerph15091971

8. Wdowiak A, Mazurek PA, Wdowiak A, Bojar I. Low frequency electromagnetic waves increase human sperm motility - A pilot study revealing the potent effect of $43 \mathrm{kHz}$ radiation. Int J Occup Med Environ Health 2018; 31(6): 723-39. https://doi.org/10.13075/ijomeh.1896.01262

9. Mossman KL. Deconstructing radiation hormesis. Health Phys. 2001; 80(3): 263-9.

10. Jaworowski Z. Radiation hormesis - a remedy for fear. Hum Exp Toxicol. 2010;29(4): 263-70, https://doi.org/10.1177/0960327110363974.

11. Liu SZ. Biological effects of low level exposures to ionizing radiation: theory and practice. Hum Exp Toxicol. 2010; 29(4): 275-81. https://doi. org/10.1177/0960327109363967

12. Kumar D, Salian SR, Kalthur G, Uppangala S, Kumari S, Challapalli S, et al. Association between sperm DNA integrity and seminal plasma antioxidant levels in health workers occupationally exposed to ionizing radiation. Environ Res. 2014; 132: 297-304. https://doi.org/10.1016/j. envres.2014.04.023

13. Wdowiak A, Mazurek PA, Wdowiak A, Bojar I. Effect of electromagnetic waves on human reproduction. Ann Agric Environ Med. 2017; 31; 24(1): 13-18. https://doi.org/10.5604/12321966.1228394

14. Wdowiak A, Bakalczuk S, Bakalczuk G. Decreased activity of superoxide dismutase in the seminal plasma of infertile men correlates with increased sperm deoxyribonucleic acid fragmentation during the first hours after sperm donation. Andrology. 2015; 3(4): 748-55. https:// doi.org/10.1111/andr.12061

15. World Health Organization. WHO Laboratory Manual for the Examination of Human Semen and Sperm-cervical Mucus Interaction. 3th ed. World Health Organization; 1992.

16. World Health Organization. WHO Laboratory Manual for the Examination of Human Semen and Sperm-cervical Mucus Interaction. 4th ed. Cambridge University Press; 1999.

17. World Health Organization. WHO Laboratory Manual for the Examination and Processing of Human Semen. 5th edn. Geneva: World Health Organization; 2010.

18. Premi S, Srivastava J, Chandy SP, Ali S. AZFc somatic microdeletions and copy number polymorphism of the DAZ genes in human males exposed to natural background radiation. Hum Genet. 2007; 121(3-4): 337-46. https://doi.org/10.1007/s00439-006-0318-7
19. Premi S, Srivastava J, Chandy SP, Ahmad J, Ali S. Tandem duplication and copy number polymorphism of the SRY gene in patients with sex chromosome anomalies and males exposed to natural background radiation. Mol Hum Reprod. 2006; 12(2): 113-21. https://doi. org/10.1093/molehr/gal012

20. Premi S, Srivastava J, Chandy SP, Ali S. Unique signatures of natural background radiation on human $\mathrm{Y}$ chromosomes from Kerala, India. PLoS One. 2009; 4(2): e4541. https://doi.org/10.1371/journal. pone.0004541

21. Pathak D, Premi S, Srivastava J, Chandy SP, Ali S. Genomic instability of the DYZ1 repeat in patients with Y chromosome anomalies and males exposed to natural background radiation. DNA Res. 2006; 13(3): 103-9. https://doi.org/10.1093/dnares/ds1002

22. Kumar D, Salian SR, Kalthur G, Uppangala S, Kumari S, Challapalli S, Chandraguthi SG, Krishnamurthy H, Jain N, Kumar P, Adiga SK. Semen abnormalities, sperm DNA damage and global hypermethylation in health workers occupationally exposed to ionizing radiation. PLoS One. 2013 Jul 29; 8(7): e69927. https://doi.org/10.1371/journal.pone.0069927

23. Kłucinski P, Wójcik A, Grabowska-Bochenek R, Gmiński J, Mazur B, Hrycek A, et al. Erythrocyte antioxidant parameters in workers occupationally exposed to low levels of ionizing radiation. Ann Agric Environ Med. 2008; 15(1): 9-12.

24. Alvarez R, Tusell L, Miró R, Genescà A, Caballín MR, Ribas M, et al. Dose-response relationship for the induction of chromosomal abnormalities in gamma-irradiated human spermatozoa. Environ Mol Mutagen. 1997; 29(4): 357-66. https://doi.org/10.1002/(SICI)10982280(1997)29:43.3.CO;2-O

25. Saiyad Musthafa M, Jawahar Ali A, Mohamed Ahadhu Shareef TH, Vijayakumar S, Iyanar K, Thangaraj K. Ionizing radiation effects on sex steroid hormone levels in serum and milt of freshwater fish Oreochromis mossambicus. Ecotoxicol Environ Saf. 2014; 101: 103-6. https://doi.org/10.1016/j.ecoenv.2013.12.015

26. Verçosa P, Falcão PH, Furtado AF. Effects of gamma irradiation on the reproductive capacity and the longevity of Panstrongylus megistus (Hemiptera: Reduviidae). Mem Inst Oswaldo Cruz. 1993; 88(2): 195201. http://dx.doi.org/10.1590/S0074-02761993000200004

27. Johnson SL, Dunleavy J, Gemmell NJ, Nakagawa S. Consistent agedependent declines in human semen quality: a systematic review and meta-analysis. Ageing Res Rev. 2015; 19: 22-33. https://doi.org/10.1016/j. arr.2014.10.007 